\title{
The Effect of Welding Position on the Quality of SMAW Welding Electrode Joint AWS E 7018
}

\author{
Ferri Safriwardy ${ }^{1}$ \\ \{ferri@unimal.ac.id\} \\ ${ }^{1}$ Department of Machine Engineering,Universitas Malikussaleh, Aceh, Indonesia
}

\begin{abstract}
The abstract should summarize the contents of the paper and should contain at least 70 and at most 200 words. It should be set in 9-point font size, justified and should have a hanging indent of 2-centimenter. There should be a space before of 12-point and after of 30-point.This study discusses the effect of welding position on the quality of welded joints using AWS E 7018 electrode. Research was designed in two stages, using the tensile test and the bending test. The result of tensile test shows the comparison of average yield strength of vertical welding position equal to $24,30 \mathrm{kgf} / \mathrm{mm} 2$, while horizontal position $22,98 \mathrm{kgf} / \mathrm{mm} 2$ and for overhead position is $24,14 \mathrm{kgf} / \mathrm{mm} 2$. For the ultimate strength in the vertical welding position is $26.06 \mathrm{kgf} / \mathrm{mm} 2$, while for the horizontal welding position is $27.93 \mathrm{kgf} / \mathrm{mm} 2$ and for overhead welding position is 22.24 $\mathrm{kgf} / \mathrm{mm} 2$. Bending test can clearly be seen the comparison of strength and durability of the material used and the position of welding used. In bending test for vertical welding position has bending strength value of 4039,67 kgf, while in horizontal welding position is $4298 \mathrm{kgf}$ and for overhead welding position is $3965,33 \mathrm{kgf}$. Although in the research results obtained the value of vertical welding position better than the position of horizontal welding and overhead welding position, but other welding positions are also feasible to use depending on the needs of welders and conditions in the field.
\end{abstract}

Keywords: The Welding Position, Mechanical Testing, SMAW, ST 37, AWS E 7018 Electrode, Welding Equipment, Welding Material.

\section{Introduction}

Welding can be interpreted as the process of joining metals or metal alloy utilizing heat energy from the welding machine used in welding. Welding processes commonly used in the industrial world such as SMAW, GMAW, SAW, and TIG. The most widely used welding is electric arc welding (SMAW). An electric arc welding with a sealed electrode is a process of joining a material which produces a fused or growing member of the material by heating it at welding temperature, by the use of filler metal or electrode. Welding has advanced and grown with varying degrees of difficulty. Various positions of welding also addded to the values such as under the hand, horizontal, and vertical to the position of over head (over the head).

Each welding position has its own constraints, especially in terms of the comfort of the welder during welding. The position of the welding is the positioning or position of the welding electrode movement. Position taken by welder usually depends on the location of the gaps to be welded. Oftentime, welding should follow the position of the construction design such as welding ceiling or building ceiling on the corner of the building, on the floor, and so on, especially in the continuous welding process that is a construction requires fast and fast 
welding with welding position vary. Given the necessity of a particular welding position, it will give different results to the strength and hardness of the weld results.

\section{Basic Theory}

\subsection{Defining of Welding}

Welding is a way to connect solid objects using heating process of joining a metal into one due to heat by the effect of pressure. The definition can be further elaborated that welding is the work of grafting two or more metals by providing heat under the liquid metal point of the mother by giving pressure or no pressure and added metal filler or not. Successful unification required several requirements that must be met, namely:

1. Metal should be able to melt by means of heat

2. Metal involved in the welding process have suitability properties which will not weaken or thwart the connection.

3. Method of the connection in accordance with the nature of the solid and the purpose of connection.

\subsection{Shielded Metal Arc Melding}

The electrode welding arc welding process known as SMAW is widely used in the industry because of its wide use capability, simple equipment, and can be used both indoor and outdoor. Welding can be used in various positions. The welding method of the arc welded electrode is used metal wire electrodes wrapped with flux, an electric arc formed between the master $\log m$ and the electrode tip. Because of the heat from this arc the parent metal and the end of the electrode melt and then freeze together.

The welding method of the enclosed electrode uses electrodes as filler metal. In addition to the use of soft steel sealed electrodes also made for strong steel, heat-resistant steel, copper alloy stainless steel and hard coating. Titan Oxide Coating or Titania Lime can enhance wear resistance [1]. Standardization of welding wire according to AWS for welding of soft steel.

\subsection{Welding Position}

According to AWS Welding [2], welding position is positioning of welding electrode movement. The position or attitude of the welding taken by the welder usually depends from the weld or welding slit workpiece to be welded. The welding position at weld consists of 4 (four) kinds of position, namely: down hand position, horizontal welding position, vertical welding position and over head position.

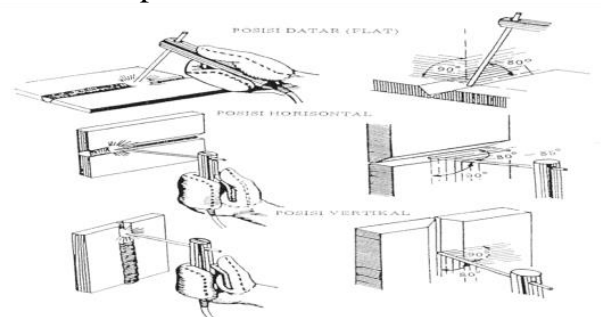

Figure 1: Types of welding positions 


\subsection{Tensile Testing}

The mechanical properties of the material obtained from tensile testing are:

1. Tensile Strength.

2. Yield Strength.

3. Ductility.

4. Elasticity.

A voltage that occurs at the time of fracture by dividing the maximum load by the initial cross-sectional area. Tensile strength is set based on the area of the origin A, load P, and voltage $\delta[3]$.

\subsection{Yield Strength}

The yield strength is the voltage required to produce a small amount of specified plastic deformation. The most commonly used definition for this property is the offset yield strength determined by the voltage associated with the intersection between the strain stress curve and the line parallel to the elastic offset of the specified strain curve.

\subsection{Tensile Strength}

The ultimate tensile strength, is the maximum load on tensile testing that occurs until the breaking of a specimen of a tensile test object.Tensile strength is the value most often written as a result of a tensile test, but in reality it is fundamental in relation to the strength of the material. For the metal clay the tensile strength must be associated with the maximum load, where the metal can withstand axial loads for very limited circumstances.

\subsection{Modulus of Elasticity}

According to George E. Dieter, 1993 The modulus of elasticity, or modulus of young is the size of a material's stiffness. The modulus of elasticity can be expressed in the stress-strain curve. Voltage is a resistance to the outer forces, while the strain is defined as the force undergoing a change of shape in a specimen.Objects can be said to be perfect elastic means that the cause force of change of form is lost, then the object will return to its original shape. Many objects that are perfectly elastic have a boundary of deformation calledthe elastic limit so that if it exceeds the elastic limit, the object will not return to its original shape.

\subsection{Bending Testing}

Bending is a plastic deformation process of metal against a linear axis with little or no change in surface area. Bending causes the metal on the outside of the neutral axis to pull, while on the other side is under pressure. The material is said to be strong if the external load only causes deformation within the elasticity limit, the amount of deformation is determined by the type of material, the magnitude and the type of load. The type of loading (style) based on the direction of the load can be distinguished upon. 


\subsection{Bending Voltage Analysis}

In a cross section of the apparatus it will undergo bending stress, assuming the length of the test specimen or the fulcrum $=\mathrm{L}(\mathrm{mm})$, and the fracture load $\mathrm{F}(\mathrm{Kgf})$, the thickness of the test specimen is $\mathrm{d}(\mathrm{mm})$, then the bending stress value is obtained using the formula.

\section{$3 \quad$ Tensile Test Material}

\subsection{Tensile Test}

The dimensions of the tensile test as shown in Figure 2 below.

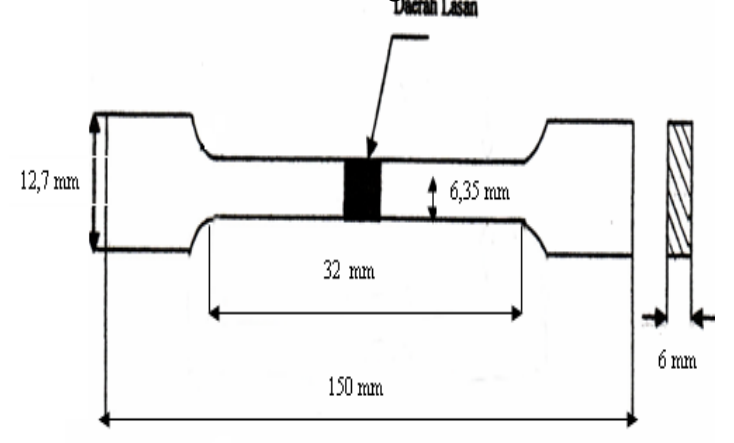

Figure 2. Standard ASTM E 8

\subsection{Bending Test Material}

The bending test material as shown in Figure3 below

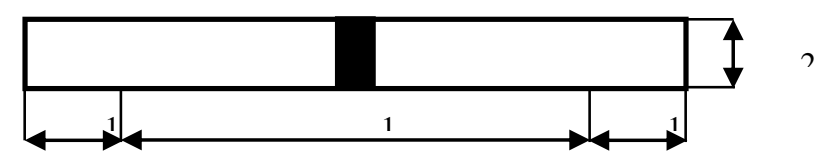

Figure 3. Dimensions of standard ASTM E 190 bending test

\section{$4 \quad$ Research Result}

Research results from the influence of the welding position to the strength of the AWS E 7018 electrode welding joints on the low carbon steel specimens can be obtained after passing the tensile test. From the bending test can be known bending strength, elastic modulus, bending strain, deflection and deflection angle.

\subsection{Tensile Test Data}

Table 1. Tensile Testing Data 


\begin{tabular}{|c|l|c|l|l|c|c|}
\hline \hline $\begin{array}{l}\text { No Test } \\
\text { Object }\end{array}$ & Position of Welding & $\begin{array}{l}\text { Cross Sectional } \\
\text { Area } \\
\left(\mathbf{m m}^{\mathbf{2}}\right)\end{array}$ & $\begin{array}{l}\text { Width } \\
(\mathbf{m m})\end{array}$ & $\begin{array}{l}\text { Thickness } \\
(\mathbf{m m})\end{array}$ & $\begin{array}{l}\text { Gauge } \\
\text { Length } \\
(\mathbf{m m})\end{array}$ & $\begin{array}{l}\text { ength } \\
\mathbf{m m})\end{array}$ \\
\hline \hline 1 & Vertikal & 38,100 & 6,35 & 6 & 32 & 150 \\
\hline 2 & Vertikal & 38,100 & 6,35 & 6 & 32 & 150 \\
\hline 3 & Vertikal & 38,100 & 6,35 & 6 & 32 & 150 \\
\hline \hline 1 & Horizontal & 38,100 & 6,35 & 6 & 32 & 150 \\
\hline 2 & Horizontal & 38,100 & 6,35 & 6 & 32 & 150 \\
\hline 3 & Horizontal & 38,100 & 6,35 & 6 & 32 & 150 \\
\hline \hline 1 & Over head & 38,100 & 6,35 & 6 & 32 & 150 \\
\hline 2 & Over head & 38,100 & 6,35 & 6 & 32 & 150 \\
\hline 3 & Over head & 38,100 & 6,35 & 6 & 32 & 150 \\
\hline \hline
\end{tabular}

Source: Research results

\subsection{Data Analysis Resultof Bending Testing}

The result of data obtained after bending test, it can be determined bending voltage, elastic modulus, bending strain, deflection and deflection angle By taking one of the test specimen horizontal position welding test that is 1 (one) test specimen from 3 (three) specimen 4.2.1 Data Analysis Result of Bending Testing.

1. Yield Strength

$$
\begin{aligned}
\sigma_{y} & =\frac{P_{y(\text { offsetregangan }=0,002)}}{A_{0}} \\
\sigma_{y} & =\left[\frac{982 \mathrm{Kgf}}{38,100 \mathrm{~mm}^{2}}\right] \\
\sigma_{y} & =25,77 \mathrm{Kgf} / \mathrm{mm}^{2} \Rightarrow 252,71 \mathrm{~N} / \mathrm{mm}^{2}
\end{aligned}
$$

2. Ultimate Tensile Strength

$$
\begin{aligned}
\sigma_{u} & =\frac{P_{u}}{A_{0}} \\
\sigma_{u} & =\frac{844 \mathrm{Kgf}}{38,100 \mathrm{~mm}^{2}} \\
\sigma_{u} & =22,15 \mathrm{Kgf} / \mathrm{mm}^{2} \Rightarrow 217,21 \mathrm{~N} / \mathrm{mm}^{2}
\end{aligned}
$$

3. Modulus of Elasticity

$$
\begin{aligned}
& E=\frac{\sigma}{\varepsilon} \\
& E=\frac{30,44 \mathrm{Kgf} / \mathrm{mm}^{2}}{6,67 \%} \\
& E=456,37 \mathrm{Kgf} / \mathrm{mm}^{2} \Rightarrow 4475,46 \mathrm{~N} / \mathrm{mm}^{2}
\end{aligned}
$$




\subsection{Bending Test Data}

Table 2: Tensile Testing Data

\begin{tabular}{|c|l|c|c|c|}
\hline \hline $\begin{array}{c}\text { No. } \\
\text { Testing } \\
\text { Object }\end{array}$ & \multicolumn{1}{|c|}{ Position } & $\begin{array}{c}\text { Width } \\
(\mathbf{m m})\end{array}$ & $\begin{array}{c}\text { Thickness } \\
(\mathbf{m m})\end{array}$ & $\begin{array}{c}\text { Length } \\
(\mathbf{m m})\end{array}$ \\
\hline \hline 1 & Vertikal & 6 & 25 & 150 \\
\hline 2 & Vertikal & 6 & 25 & 150 \\
\hline 3 & Vertikal & 6 & 25 & 150 \\
\hline 1 & Horizontal & 6 & 25 & 150 \\
\hline \hline 2 & Horizontal & 6 & 25 & 150 \\
\hline 3 & Horizontal & 6 & 25 & 150 \\
\hline 1 & Over head & 6 & 25 & 150 \\
\hline 2 & Over head & 6 & 25 & 150 \\
\hline 3 & Over head & & 25 & 150 \\
\hline \hline
\end{tabular}

Source: Research Results

1.Bending Tensity

$$
\begin{aligned}
\tau & =\frac{3 F L}{2 b d^{2}} \\
\tau & =\frac{3(4399 \mathrm{Kgf})(150 \mathrm{~mm})}{2(25 \mathrm{~mm})(6 \mathrm{~mm})^{2}} \\
\tau & =\frac{1979550}{1800} \\
\tau & =1099,75 \mathrm{Kgf} / \mathrm{mm}^{2}
\end{aligned}
$$

2. Modulus of elasticity

$$
\begin{aligned}
& E=\frac{F L^{3}}{4 . \delta b d^{3}} \\
& E=\frac{4399 \mathrm{Kgf}(150 \mathrm{~mm})^{3}}{4(328,71 \mathrm{~mm})(25 \mathrm{~mm})(6 \mathrm{~mm})^{3}} \\
& E=\frac{4399.150^{3}}{7100136} \\
& E=2091,03 \mathrm{Kg} / \mathrm{mm}^{2}
\end{aligned}
$$

3 Bending Strain 


$$
\begin{aligned}
& \varepsilon_{x}=\frac{3 y F L}{E b d^{3}} \\
& \varepsilon_{x}=\frac{3(3 \mathrm{~mm})(4399 \mathrm{Kgf})(150 \mathrm{~mm})}{\left(2091,03 \mathrm{Kgf} / \mathrm{mm}^{2}\right)(25 \mathrm{~mm})(6 \mathrm{~mm})^{3}} \\
& \varepsilon_{x}=\frac{5938650}{11291562} \\
& \varepsilon_{x}=0,52 \%
\end{aligned}
$$

4 Deflection

$$
\begin{aligned}
& \delta=\frac{F L^{3}}{48 E I} \\
& \delta=\frac{4912 K g f(150 \mathrm{~mm})^{3}}{48\left(2091 \mathrm{Kg} / \mathrm{mm}^{2}\right)(450 \mathrm{~mm})} \\
& \delta=\frac{4912.150^{3}}{45165600} \\
& \delta=367,04 \mathrm{~mm}
\end{aligned}
$$

5 Deflection Angle

$$
\begin{aligned}
& I=\frac{b d^{3}}{12 m^{4}} \\
& I=\frac{25 m m(6 m m)^{3}}{12 m^{4}} \\
& I=\frac{5400}{12} \\
& I=450 \mathrm{~mm}^{4}
\end{aligned}
$$

Therefore, deflection angle can be calculated as follows:

$$
\theta=\frac{F L^{2}}{16 E I}
$$




$$
\begin{aligned}
& \theta=\frac{4219 \mathrm{Kg} f(150 \mathrm{~mm})^{2}}{16\left(2091,03 \mathrm{Kg} / \mathrm{mm}^{2}\right)\left(450 \mathrm{~mm}^{4}\right)} \\
& \theta=\frac{994927500}{1505416} \\
& \theta=6,30^{\circ}
\end{aligned}
$$

\section{Conclusions}

1. Horizontal welding position is better than vertical welding position and over head to weld result by using low carbon steel material and AWS E7018 electrode.

2. The position of welding gives a real effect on the weld result, it can be seen from the tensile test where the position of horizontal welding is $27.93 \mathrm{kgf} / \mathrm{mm} 2$, vertical welding position is $26.06 \mathrm{kgf} / \mathrm{mm} 2$ and for overhead welding position is $22,24 \mathrm{kgf} / \mathrm{mm} 2$.

3. On testing of this bending strength obtained the position of horizontal welding is higher than the value of other welding position, but other welding position is also suitable to be used depending on the conditions of the field.

\section{References}

[1] Anonym, 2000. Modul Pengetahuan Elektroda Las, PT. Atmindo, Medan.

[2] Anonym, 2000. Modul Pengetahuan Elektroda Las, PT. Atmindo, Medan.

[3] Anonym, 2003.Modul Pendidikan dan Pelatihan Inspektur Las dan Aplikasi Pengelasan , Bandung.

[4] Anonym, 2006.Panduan Penulisan Tugas Akhir (TGA) Jurusan Teknik Mesin Fakultas Teknik Universitas Malikussaleh, Universitas Malikussaleh. Lancang Garam Lhokseumawe.

[5] Anonym, 2010. Modul Pengetahuan Pengelasan, PT. Atmindo. Medan.

[6] Agussalim, Analisa Sifat Mekanik Kekuatan Sambungan Las Rangka Baja SS41 Digunakan Pada Kendaraan Angkutan Penumpang Alternatif, Universitas Malikussaleh 2007.

[7] Charlotte Welsman, 1970, AWS Welding Hand Book Volume 1 Edisi 7, Miami Florida, USA.

[8] George E. Dieter, Sriati Djaprie, 1993, Metalurgi Mekanik, Edisi ketiga Penerbit Erlangga, Jakarta.

[9] Okumura, Harsono W, 1991, Teknologi Pengelasan Logam, Pradnya Paramita, Jakarta.

[10] Rijal Fajri, Kaji Perbedaan Kekuatan Sambungan Las Antara Kawat Las OK 53.04 dan TH-216, Universitas Malikussaleh 2008.

[11] Saiful Z, 2008. Studi Tentang Pengaruh Kekuatan Pengelasan Terhadap Baja Karbon Rendah Stk41 Untuk Pipa, Universitas Malikussaleh. 